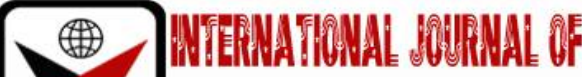

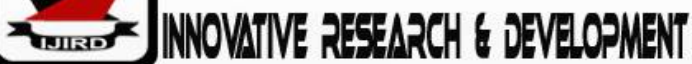

ISSN 2278 - 0211 (Online)

\section{Business Strategies: An Antidote to Firm Profitability of Selected Flour Milling Companies in Nigeria}

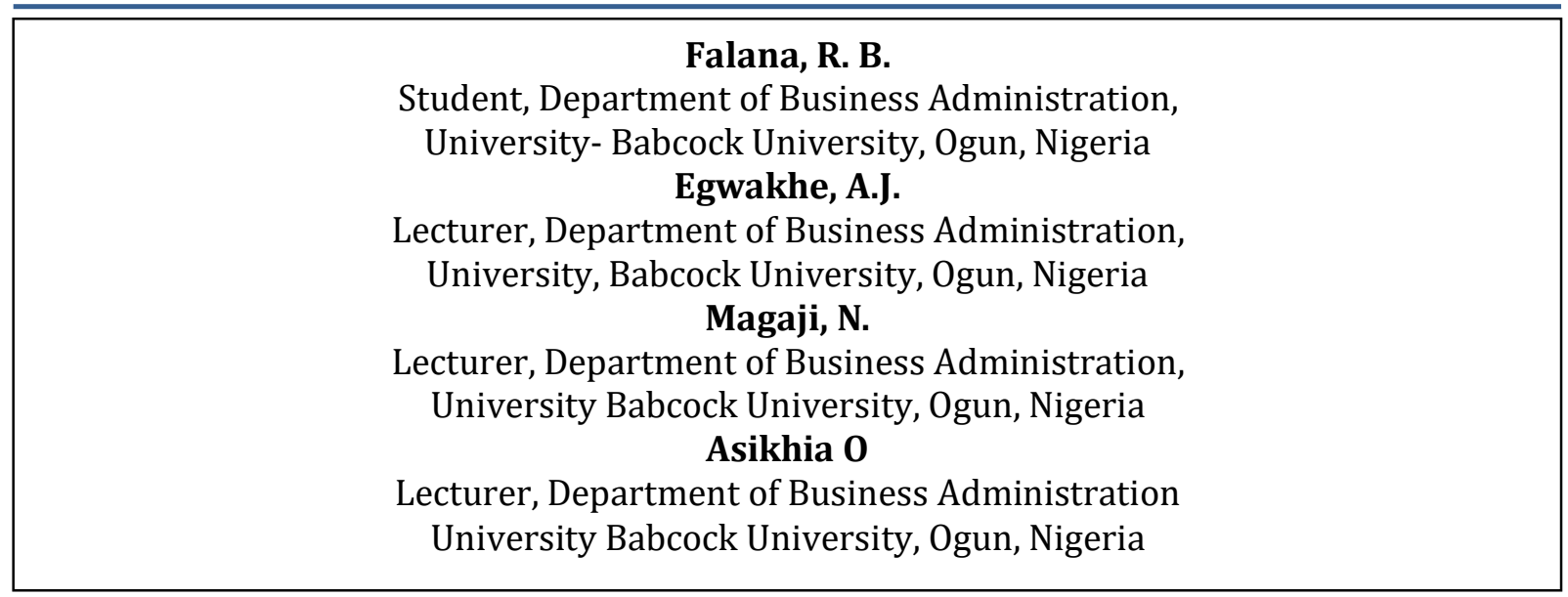

\section{Abstract:}

The study of business strategies has drawn so much attention among business practitioners and academic researchers in the last two decades as globalization came fully into limelight. However, in Nigeria, there are few studies conducted to investigate the relationship between business strategies and firm profitability. This paper examined the effect of business strategies on profitability of selected flour milling companies in Nigeria. Data were collected through validated questionnaire administered to sixty eight respondents after establishing the reliability test. Multiple regression analysis was conducted to depict competitive advantage as a function of business strategies. The results $\left(R^{2}\right.$ is $0.396\left(F_{(6,597)}=\right.$ 66.953, $p=0.000$ ) indicated that business strategies significantly affected profitability. However, the study also indicated that cost leadership ( $\beta=0.288, t=6.226, p<0.05)$, product differentiation $(\beta=0.283, t=6.039, p<0.05)$ business diversification ( $\beta=0.110, t=2.415, p<0.05)$ and regrouping $(\beta=0.127, t=2.933, p<0.05)$ have positive and significant effect on firm profitability in selected flour milling companies in Nigeria The result further showed that backward integration $(\beta=0.030, t=0.779, p>0.05)$ has a positive and insignificant effect on firm profitability while market development $(\beta=-0.015, t=-0.381, p>0.05)$ has a negative and insignificant effect on firm profitability in selected flour milling companies in Nigeria. The study recommends that production firms most especially the flour millers should integrate their business strategies with their day to day operations efficiently to enhance their backward integration, and market development they should also adopt the strategy/models that was developed in this study to align with their operations and target customers.

Keywords: Business strategies, market development, business diversification. profitability

\section{Introduction}

In today's world, there is a rapid change in the business environment such that the product-market competition is ever increasing among industries, information technology improving in various industries as the day goes by in a way that firms use internet facilities and social network to advertise and market their products and services. To compete successfully in this present competitive business environment, firms continually need to make some strategies and take some actions by improving product quality and productivity, reducing product cost, promoting product and process innovations, and improving product speed to the market and customers' goodwill. Firms therefore need to strive to be at par with the global change, achieving competitive advantage position and enhancing performance relative to their competitors. Firm profitability is an enabler for firm to open other business locations, acquire target market and helps in expanding operations into foreign countries.

Several scholars (Axjonow, Ernstberger, \& Pott, 2018; Dang, Li, \& Yang, 2018; Hussain, Rigoni, \& Orij, 2018; Platonova, Asutay, Dixon, \& Mohammad, 2018; Shuen, 2018) have looked at business strategies and net profit margin, business strategies and financial performance, business strategies and firm size and business strategies and productivity. However, limited studies have looked at the relationship that exists between business strategies and overall organisational profitability (Altavilla, Boucinha, \& Peydró, 2018). Hence, leaving a gaps in academic literature yet to be filled from the context of flour milling firms in Nigeria (Bala \& Alhassan 2018). 
Several scholars (Axjonow, Ernstberger, \& Pott, 2018; Dang, Li, \& Yang, 2018; Hussain, Rigoni, \& Orij, 2018; Platonova, Asutay, Dixon, \& Mohammad, 2018; Shuen, 2018) have looked at business strategies and net profit margin, business strategies and financial performance, business strategies and firm size and business strategies and productivity. However, limited studies have looked at the relationship that exists between business strategies and overall organisational profitability (Altavilla, Boucinha, \& Peydró, 2018). Hence, leaving a gaps in academic literature yet to be filled from the context of flour milling firms in Nigeria (Bala \& Alhassan 2018).

Evidence from the financial statements of flour milling companies in Nigeria as at December 31, 2018 revealed a total net profit decline of N8.158 billion as reported by Opara (2018) asserted that as at year ended 31st March 2019, revealed that the top two market movers in flour mills companies dropped drastically by $74.04 \%$ in 2019 to N4.68billion as against N18.03bn in 2018 (FMN, 2019). This trend has been attributed to the rising operational cost, arising from inability to adopt business strategies capable of reducing cost centres and shoring up profit levels (Kajola, Olabisi, Ajayi, \& Agbatogun, 2018). Strategies such as backward integration and regrouping, have been avoided by these firms as a lot of over-reliance in the sourcing of raw materials through importation and/or outright domestic purchase from suppliers creating a new for urgent alignment with business strategies targeted at growing profitability.

Odebode and Aras (2019) study revealed that business strategies positively influence the firm profitability and thus, performance. Ansoff, Kipley, Lewis, Helm-Stevens, and Ansoff (2019) found a positive relationship between profitability level of a company and business strategies. Moreover, O'brien (2019) found positive relationship between profitability and business strategies. Örsdemir, Deshpande, and Parlaktürk (2018) found positive relationship between profitability of the firm and business strategy. Similar results were found by Gupta, and Aggarwal (2016). While Adekola, Samy, and Knight (2017) argued that business strategies ensures the cost incurred in production is minimal and promotes economy in purchase.

Spyropoulou, Katsikeas, Skarmeas, and Morgan (2018) study has revealed that business strategies negatively influence the firm profit and thus, performance. Sensing capabilities are useful in identification and assessment of an opportunity within firm's environment. Studies that exist on business strategies and firm profitability in flour milling industries in Nigeria are limited thus, this study therefore seek to examine how business strategies cost leadership, product differentiation, backward integration, market development, business diversification and regression) affect firm profitability of selected flour milling companies in Nigeria.

\section{Review of Literature}

\subsection{Business Strategies and Firm Profitability}

Firm profitability is a core measure of business performance which constitutes an essential aspect of its financial report (Lubner, 2019). Liu, Xie, and Xu (2019) defined profitability as a measurement of efficiency which ultimately leads to it its success or failure. Hui, Liang, and Yeung (2019) viewed firm profitability as a business' ability to produce a return on an investment due to resources committed in comparison with an alternative investment. Estrada, and Dong (2019) contributed that firm profitability is the total income earned by the enterprise during the specified period of time. Prasad, Sivasankaran, and Shukla (2019) argued that firm profitability is the operating efficiency of the enterprise which could be explained as profitability. Ahmad, Li, and Tian (2019) contributed that is the ability for the enterprise to make profit on sales, while Pellegrini, Caruso, and Cifone (2019) sees it as the ability for the enterprise to get sufficient return on the capital and employee used in the business operations.

Cassia and Magno (2019) mentioned that strategies have long term prosperity of a business enterprise; it is concerned with long term asset growth, not short term profit. Thus businesses need strategies in order to ensure that resources are allocated in the most effective way (Eisman, Kilbourne, Dopp, Saldana, \& Eisenberg, 2019). Kara (2019) opined that strategies is a plan of actions in other to achieve long term plan of business. However argued that, strategies provides guidance to the entire management of an organisation by making clear what the company wants to achieve and what it has to do and the pathways it needs to follow to be where it will like to be in the market place. Graça and Zylbersztajn (2019) described strategies as the art of planning and directing overall activities in the organisations. Boehm, Burdick, Reinwald, Sen, Tatikonda, Tian, and Vaithyanathan (2019) Portrayed strategies from an organisation purpose point of view and explains strategies as the understanding of all organisational activities and creating awareness on the necessary areas of change.

Cost leadership provides better profit for organisations because they focused on creating low-cost operations within their industries (Bita, Kubaison, \& Muketha, 2016). An and Lifen (2016) stated that, one of the importance of cost leadership is that, it increases organisations market shear, in the sense that, it helps to achieve a higher profit margin and helps to improve to market shear. Anwar's (2016) opinions is that it improves sustainability for businesses. Gakuya and Mbugua (2018) opined that it creates capital that can be used for growth because it promotes the availability for more capital resources even though the retail cost of goods and services are low the higher margins makes it possible to retain capital from each transactions.

Product differentiation provides protection against rivalry (Cowling, Mroczkowski, \& Tanewski, 2017). Sanusi, Noor, Omar, Sanusi, and Alias (2017) stated that product differentiation strategy provides high margin that enables firms deal with supplier power and as such supplier power decreases because there is a certain amount of prestige associated with being the supplier to a producer of highly differentiated products and services.

Backward integration is very important because it helps business firms to control most especially in the through the areas of production to the distribution stage Lawrence, Crecelius, Scheer and Patil (2019). According to Adeyeye, 
Egbetokun, Opele, Oluwatope and Sanni (2018) stated that backward integration is important because it helps businesses to gain more control over their value chain.

According to Maury (2018) market development helps companies to move new products into the marketplace, expand their existing reach, or expand the use of their current products to do new things. Clemons, (2019) added that market development helps in the area of Geography, Customer base and products. Papadas, Avlonitis, Carrigan, and Piha, (2019) further explained that Geography involves the organisation expanding their footprint by expanding their product into new markets where they currently don't exist.

Business diversification are used to expand the firm's operations by adding markets, products, services or stages or production to the existing business (Jensen, Rust, \& Mackool, 2018). Endrejat and Kauffeld (2018) added that it helps to creates new competitive strengths and capabilities. Anifowose, Rashid, Annuar, and Ibrahim (2018) argued that it helps in building shareholder value by capturing cross business strategic fits.

Regrouping offer the possibility of greater financial returns than liquidating the company Ituarte, Salmi, Ballardini, Tuomi, and Partanen (2017). According to Alpeza, Tall, and Juric (2018) stated that, one the advantages of regrouping is that it provides a tremendous relief for worried directors, this can result to a company regrouping. Viotti, Converso, Hamblin, Guidetti, and Arnetz (2018) opined that it help to achieve the best course of action so that trading can continue.

\subsection{Business Strategies and Firm Profitability}

Profitability as well as business strategies was used by a number of researchers as an explanatory variable for differences in disclosure level. However, the relationship between business strategies and firm profitability disclosure is arguably one of the most controversial issues yet to be solved (Kafouros \& Aliyev 2016). Various studies have found positive while some have found negative while some have a non-significant relationship between size of business and its profitability. Some studies have reached a consensus of positive relationship between business strategies and profitability of firms. Some of these researchers include; Bodhanwala and Bodhanwala (2018) who found a positive relationship between profitability level of a company and business strategies. Also, according to Dobni, and Sand (2018) the adoption of business strategies is capable of improving the performance and profitability of organisation.

Oyedokun, Tomomewo, and Owolabi (2019) from the result of their findings posits that business strategies will not only increase profitability of the business, but will help the profitability of the capital market in Nigeria's economic growth. Nakatani (2019) examined the relationship between adopting these tools and firms' profitability in New Zealand found a significant association between the diffusion of the business strategies tools and firm profitability. However, some studies found opposite. Such studies include; who failed to find any significant positive relationship between profitability and business strategy. Bodhanwala and Bodhanwala (2018) found a negative relationship between profitability of the firm and business strategy. This suggests that small business gets lower profit compares to large business. Similar results are found by Örsdemir et al. (2018) The negative association is explained by the size itself; large firms may have management issues.

The findings from Pervan, Curak, and Pavic Kramaric (2018) give mixed results. González-Rodríguez et al. (2018). Results indicated that size affects negatively for big firms and positively for smaller firms. The latter study concludes that large firms earn the highest profits followed by smaller ones. Positive association between size and firms performance are also confirmed by the study done by Wheelock and Wilson (2018). Large firms operate at high costs because of economies of scale and can raise capital at larger costs. All these, leads to high profits. A few researchers have found that size of business has no significant role in determining its profitability (Wadho \& Chaudhry 2018; Dávila, Durst, \& Varvakis 2018). Bui and De Villiers (2017) examines how business strategies are created. The findings from the study reveal that business strategies are developed and renewed through continuous internal activities and external activities. While Kim, Song, and Triche (2015) studied resource-based view of business lifecycles and introduced the concept of business lifecycle. The study concluded that the resource-based view must include, as one of its prime components, an understanding of the evolution of resources and business strategies.

This study is however anchored on the dynamic capability theory. This theory focus on the ability of a firm to use business strategies that are coming up in the business environment, build strategic asset using diverse business strategies that would enable them to compete and or transform asset that are existing within the firm to suits changes that are occurring within the business environment thereby enhancing the firm profitability.

\section{Methodology}

This study utilized cross sectional survey research design. The reasons for adopting this method was because it collate people's experiences and information there behavioural pattern. (Flynn, Pagell, \& Fugate, 2018). the flour milling companies was selected because they are the largest food and agro allied companies in Nigeria (MAN, 2019). top and funtional level management of flour milling companies in Lagos state nigeria are the sample size of this study. they are selected simply beause they are incharge of the top positions in the companies.Total enumeration method (678) was adopted for this study because the numbers are small (Flynn, Pagell, \& Fugate, 2018). Lagos state was selected because flour milling companies head offices are located in Lagos Nigeria (MAN, 2019). The study used an adapted structural questionnaire the content, construct and criterion were critically examined before used. Multicollinearity test, Normality test and Homoscedasticity test was conducted on this study. Linearity test $(\mathrm{P}<0.05)$ shows the significance level and multi collinearity test which reveals that the VIF values of all the independent sub-variables of Business strategies are less than 10 and when the tolerance (1/VIF) is greater than 0.1 . skewness, shows a negative value less than $1(-1$ to -2$)$ means we 
have a skewed data, and a positive value more than 1 (1 to 2 ) means we have a skewed data. The above result shows that the instrument are reliable (Elhance \& Ihance, 1988).

\subsection{Econometric model specification of the study}

$\mathrm{Y}=\mathrm{f}(\mathrm{X})$

$\mathrm{FP}=\mathrm{f}(\mathrm{FP}, \mathrm{BS}, \mathrm{CL}, \mathrm{PD}, \mathrm{BI}, \mathrm{BD}, \mathrm{BDI}, \mathrm{RG})$ Functional Relationship 1

$\mathrm{BS}=(\mathrm{FP}, \mathrm{BS}, \mathrm{CL}, \mathrm{PD}, \mathrm{BI}, \mathrm{BD}, \mathrm{BDI}, \mathrm{RG})$

$\mathrm{y}_{1}=$ Firm Profitability (FP)

$\mathrm{X}=$ Business Strategies (BS)

$\mathrm{X}=\left(\mathrm{x}_{1}, \mathrm{x}_{2}, \mathrm{x}_{3}, \mathrm{x}_{4} . \mathrm{X}_{5}, \mathrm{x}_{6}\right)$

Where;

$\mathrm{x} 1=$ Cost Leadership (CL)

$\mathrm{x}_{2}=$ Product Differentiation (PD)

$\mathrm{x}_{3}=$ Backward Integration (BI)

$\mathrm{x}_{4}=$ Business Development (BD)

$\mathrm{X}_{5}=$ Business Diversification (BDI)

$\mathrm{x}_{6}=$ Regrouping $(\mathrm{RG})$

\section{Results and Discussion of Findings}

\subsection{Restatement of Hypothesis Two}

- $\mathrm{H}_{02}$ : - Business strategies have no significant effect on firm profitability in selected flour milling companies in Nigeria.

To test hypothesis two, multiple linear regression analysis was used. The independent variable of the study was business strategies while the dependent variable was firm profitability. The data for business strategies was generated by adding all the responses of cost leadership, product differentiation, backward integration, market development, business diversification, and regrouping. Also, data for firm profitability was generated by adding the scores of the items of the variable. Data from six hundred and four (604) respondents were gathered and analyzed using SPSS version 23 software. The results of the multiple linear regression analysis are shown in Table 1.

\begin{tabular}{|c|c|c|c|c|c|c|c|c|}
\hline $\mathbf{N}$ & Model & $B$ & Sig. & $\mathbf{T}$ & $\begin{array}{c}\text { ANOVA } \\
\text { (Sig.) }\end{array}$ & $\mathbf{R}^{2}$ & $\begin{array}{c}\text { Adjusted } \\
\mathbf{R}^{2}\end{array}$ & $F$ (df) \\
\hline \multirow{9}{*}{604} & (Constant) & 0.765 & 0.000 & 3.884 & \multirow{7}{*}{$0.000^{\mathrm{b}}$} & \multirow{7}{*}{0.402} & \multirow{7}{*}{0.396} & \multirow{7}{*}{$\begin{array}{l}66.953 \\
(6,597)\end{array}$} \\
\hline & Cost Leadership & 0.288 & 0.000 & 6.226 & & & & \\
\hline & $\begin{array}{l}\text { Product } \\
\text { Differentiation }\end{array}$ & 0.283 & 0.000 & 6.039 & & & & \\
\hline & $\begin{array}{l}\text { Backward } \\
\text { Integration }\end{array}$ & 0.030 & 0.437 & 0.779 & & & & \\
\hline & Market Development & -0.015 & 0.703 & -0.381 & & & & \\
\hline & $\begin{array}{l}\text { Business } \\
\text { Diversification }\end{array}$ & 0.110 & 0.016 & 2.415 & & & & \\
\hline & Regrouping & 0.127 & 0.003 & 2.933 & & & & \\
\hline & \multirow{2}{*}{\multicolumn{4}{|c|}{$\begin{array}{l}\text { Predictors: (Constant), Regrouping, Cost Leadership, } \\
\text { Backward Integration, Product Differentiation } \\
\text { Dependent Variable: Firm Profitability }\end{array}$}} & \multirow{2}{*}{\multicolumn{2}{|c|}{ Market Developme }} & Business & Diversificati \\
\hline & & & & & & & & \\
\hline
\end{tabular}

Table 1: Summary of Multiple Regression Analysis for Effects of Business

Strategies on Firm Profitability in Selected Flour Milling in Nigeria

Source: Field Survey, 2020

\subsection{Interpretation}

The analysis in Table 4.210 reveals the result of the multiple linear regression analysis on the effect of business strategies (cost leadership, product differentiation, backward integration, market development, business diversification, and regrouping) on firm profitability in selected flour milling companies in Nigeria. The analysis revealed that four out of six dimensions of business strategies have significant effect on firm profitability in selected flour milling companies in Nigeria. The result showed that cost leadership $(\beta=0.288, t=6.226, p<0.05)$, product differentiation $(\beta=0.283, t=6.039$, $\mathrm{p}<0.05)$, business diversification $(\beta=0.110, \mathrm{t}=2.415, \mathrm{p}<0.05)$ and regrouping $(\beta=0.127, \mathrm{t}=2.933$, $\mathrm{p}<0.05)$ have positive and significant effect on firm profitability in selected flour milling companies in Nigeria. The result further showed that backward integration $(\beta=0.030, t=0.779, p>0.05)$ has a positive and insignificant effect on firm profitability while market development $(\beta=-0.015, t=-0.381, p>0.05)$ has a negative and insignificant effect on firm profitability in selected flour milling companies in Nigeria. The result inferred that out of all the sub-variables of business strategies, only cost leadership, product differentiation, business diversification and regrouping have significant effect on firm profitability which implies that these sub-variables are significant in helping flour milling companies achieve profitability in the flour milling sector in Nigeria. 
Also, the $\mathrm{R}^{2}$ value, which is the coefficient of determination is 0.402 indicates that business strategies have a weak positive and significant effect on firm profitability in selected flour milling companies in Nigeria. The coefficient of multiple determination, adjusted $\mathrm{R}^{2}$ is $0.396\left(\mathrm{~F}_{(6,597)}=66.953, \mathrm{p}=0.000\right)$ indicates that business strategies explained $39.6 \%$ of the changes in firm profitability in the selected flour milling companies in Nigeria while the remaining $60.4 \%$ could be attributed to other factors not included in this model. Also, the F-statistics $(\mathrm{df}=6,597)=66.953$ at $p=0.000(\mathrm{p}<0.05)$ indicates that the overall model is significant in predicting the effect of business strategies on firm profitability. This implies that business strategies have a significant effect on firm profitability in selected flour milling companies in Nigeria. The multiple regression model is expressed as thus:

$\mathrm{FP}=0.765+0.288 \mathrm{CL}+0.283 \mathrm{PD}+0.110 \mathrm{BD}+0.127 \mathrm{RG} \ldots \ldots . \mathrm{eq} . \mathrm{ii}$

Where:

FP = Firm Profitability

$\mathrm{CL}=$ Cost Leadership

$\mathrm{PD}=$ Product Differentiation

$\mathrm{BD}=$ Business Diversification

$\mathrm{RG}=$ Regrouping

The regression model shows that holding business strategies sub-variables to a constant zero, firm profitability would be 0.765 . This means that without business strategies sub-variables, firm profitability would be positive at 0.765 . The analysis also showed that when cost leadership, product differentiation, business diversification and regrouping are improved by one unit, firm profitability would increase by $0.288,0.283,0.110$ and 0.127 respectively. This indicates that an increase in cost leadership, product differentiation, business diversification and regrouping would lead to a subsequent increase in firm profitability in selected flour milling companies in Nigeria. The result of the analysis indicates that flour milling companies should adopt business strategies such as cost leadership, product differentiation, business diversification and regrouping to achieve firm profitability. Therefore, the null hypothesis $\left(\mathrm{H}_{02}\right)$ which states that business strategies have no significant effect on firm profitability in selected flour milling companies in Nigeria was rejected.

\section{Discussion of Findings}

The result of findings of multiple regression analysis on the effect of business strategies on firm profitability of organizational performance of selected flour milling companies in Nigeria reveal that business strategies has positive and significant effect on competitive advantage especially in cost leadership, product differentiation, Regrouping, and market development.

Conceptually, the results shows that this companies has been engaging in cost leadership which means they have been reducing cost and producing the least expensive goods so as to encourage their customers. Product differentiation, it shows that this companies has been creating differences their product. It shows that the companies have been able to recast their organizational structure in other to gain desired results. Market development, the results also shows that they have been getting into new market and creating new products into new market segment. The results that there is a positive and significant relationship between business strategies and firm profitability which means that they have been making profit on all their sales.

Empirically, this result corroborates with Bodhanwala and Bodhanwala (2018) who found a positive relationship between profitability level of a company and business strategies. Also, according to Dobni, andSand (2018) the adoption of business strategies is capable of improving the performance and profitability of organisation. Oyedokun, Tomomewo, and Owolabi (2019) from the result of their findings posits that business strategies will not only increase profitability of the business, but will help the profitability of the capital market in Nigeria's economic growth. Nakatani (2019) trying to use the business strategies theory to understand the diffusion of some strategic tools that has been used in the past; they examined the relationship between adopting these tools and firms' profitability in New Zealand. They find a significant association between the diffusion of the business strategies tools and firm profitability. Ball, Gerakos, Linnainmaa, and Nikolaev (2015) opined that for an organisation to have high profitability over contemporaries, there is need for business strategies. Bui and De Villiers (2017) examines how business strategies are created. The findings from the study reveal that business strategies are developed and renewed through continuous internal activities and external activities. While Kim, Song, and Triche (2015) studied resource-based view of business lifecycles and introduced the concept of business lifecycle. They argued that the business lifecycle provides a structure for a more comprehensive approach to resourcebased view theory. The study concluded that the resource-based view must include, as one of its prime components, an understanding of the evolution of resources and business strategies. Xu, Lehmann, García de Jalón, and Ghaley (2019) found that among eight manufacturing firms in Denmark, the micro foundations identified are elements of sensing, seizing and reconfiguring, although with some variations in the extent to which they implemented and activated business strategies. This finding is also collaborated by Van Leeuwen, and Mohnen (2017) who examined how firms in the Netherlands located profitability; found that profitability in business strategies rests to a large extent on the ability of firms to sense opportunities for accessing new external resources seize these resources and reconfigure them internally. Weche, and Wambach (2018), Kostin, Macowski, Pietrobelli, Guillén-Gosálbez, Jiménez, and Ravagnani (2018) who worked in Europe and Brazil respectively found that implementing business strategies in the manufacturing firms demanded changes in general management processes and reconfiguration of firm profitabilities, as well as new organisational designs for the purpose of developing the necessary profitabilities to manage different business strategies. Edmondson and Edmondson (2018) examined the role of the external environment on the effect of business strategies. It was found that business strategies have a positive effect on sales growth and when firms are faced with increasing levels 
of competitive intensity. To test their hypothesis the authors used financial data and non-financial data from large Australian firms. Spyropoulou, Katsikeas, Skarmeas, and Morgan (2018) study has revealed that business strategies positively influence the firm profit and thus, performance. Sensing capabilities are useful in identification and assessment of an opportunity within firm's environment. This involved exploring technological opportunities, probing markets, and listening to customers, along with scanning the other elements of the business ecosystem. Seizing business strategies help in mobilization of resources to address an opportunity and to capture value. These business strategies include designing business models to satisfy customers. They also include securing access to capital and the necessary human resource Olson, Slater, Hult, and Olson (2018). Transforming business strategies are important for continued renewal and are needed when radical new opportunities are to be addressed. Also, they are needed periodically to soften the rigidities that develop over time from asset accumulation, standard operating procedures, and insider misappropriation of rent streams.

On the contrary, Edmondson and Edmondson (2018) examined the role of the external environment on the effect of business strategies. It was found that business strategies has negative effect on firm profitability and when firms are faced with increasing levels of competitive intensity. To test their hypothesis the authors used financial data and nonfinancial data from large Australian firms. Spyropoulou, Katsikeas, Skarmeas, and Morgan (2018) study has revealed that business strategies negatively influence the firm profit and thus, performance. Based on this majority of findings that business strategies has significant effect on firm profitability, therefore the study rejected the null hypothesis two $\left(\mathrm{H}_{01}\right)$ that business strategies have no significant effect on firm profitability.

Theoretically, resource based view theory supported the findings that cost leadership, product differentiation, Regrouping, and market development can be employed to generate firm profitability for an organization and hence increasing organizational performance. Resource based view theory holds the assumptions which states that resources must be heterogeneous in nature. The heterogeneous in nature of resources assumes that firms achieve more profit when their resources are significantly different from that of competitors. Considering the support of the resource based view theory to the effect that business strategies has significant effect on firm profitability the study therefore rejected the null hypothesis two $\left(\mathrm{H}_{01}\right)$ that business strategies have no significant effect on firm profitability.

\section{Conclusion and Recommendations}

This paper examined business strategies (cost leadership, product differentiation, backward integration, market development, business diversification, and regrouping) effect on profitability with focus on selected flour milling companies in Nigeria. The results showed that the business strategies components jointly affect profitability positively. However, the individual effect differs in terms of statistical significance, direction and relative effect. While cost leadership, product differentiation, backward integration and regrouping revealed no significant effects on profitability, market development and business diversification showed positive and significant effects on profitability. Thus, the study concluded that organizations should focus on adopting competitive strategies so as to improve organizational profitability through increasing customer base, asset quality, quality of service and increased market share and that flour milling companies should strategically harness the opportunities in competitive dynamics to strengthen their competitive capability and achieve desired corporate performance.

Top management of Flour mill of Nigeria Plc, Dangote flour mill Plc, and Honeywell flour mill Plc in making corrective decisions well in time should use the of linear regression methods in their production planning. This method will determine the future production patterns and outlook resulting in the establishment of new production units, while planning for maximizing profits of the company. Production firms most especially the flour millers should integrate their business strategies with their day to day operations efficiently to enhance their sales and profitability and also adopt the strategy/models that was developed in this study to align with their operations and target customers. Profitability growth as one of the key preconditions to survive in the market is forcing companies to compete on global markets and at the same time defend domestic market share from their global competitors, the effect of that is increased complexity of supply chains, pressure to decrease cost burden and improve service level. To cope with the complexity of production, increase customer requirements, and profitability efficient management of the supply chain is a prerequisite. Further study should be conducted in other sectors and other business strategy proxies that was not studied in this research should be invested in further studies and also be conducted in other cities.

Based on the aforementioned this study concludes that since the study established business strategies significantly which affect firm profitability in selected flour milling companies in Nigeria, therefore flour milling companies should continue to adopt business strategies so as as to contionously record high rate of profitability.

\section{References}

i. Adekola, A., Samy, M., \& Knight, D. (2017). Efficient working capital management as the tool for driving profitability and liquidity: a correlation analysis of Nigerian companies. International Journal of Business and Globalisation, 18(2), 251-275.

ii. Ahmad, N., Li, H.-Z., \& Tian, X.-L. (2019). Increased firm profitability under a nationwide environmental information disclosure program? Evidence from China. Journal of Cleaner Production, 230, 1176-1187.

iii. Altavilla, C., Boucinha, M., \& Peydró, J.-L. (2018). Monetary policy and bank profitability in a low interest rate environment. Economic Policy, 33(96), 531-586.

iv. Ansoff, H. I., Kipley, D., Lewis, A., Helm-Stevens, R., \& Ansoff, R. (2019). Societal strategy for the business firm Implanting Strategic Management (pp. 285-310): Springer. 
v. An, G., \& Lifen, C. (2016). Explore the Integration of Cost Leadership Strategy and Differentiation Strategy. Paper presented at the 7th International Conference on Education, Management, Information and Computer Science (ICEMC 2017).667-998.

vi. Anwar, K. (2016). Comparison between cost leadership and differentiation strategy in agricultural businesses. custos e agronegocio on line, 12(2), 212-231.

vii. Axjonow, A., Ernstberger, J., \& Pott, C. (2018). The impact of corporate social responsibility disclosure on corporate reputation: A non-professional stakeholder perspective. Journal of Business Ethics, 151(2), 429-450.

viii. Adeyeye, D., Egbetokun, A., Opele, J., Oluwatope, O., \& Sanni, M. (2018). How barriers influence firms'search strategies and innovative performance. International Journal of Innovation Management, 22(02), 185-201.

ix. Alpeza, M., Tall, J., \& Juric, P. M. (2018). The challenges of sme business transfers: The evidence from croatia and finland. Organizacija, 51(2), 135-145.

X. Anifowose, M., Abdul Rashid, H. M., Annuar, H. A., \& Ibrahim, H. (2018). Intellectual capital efficiency and corporate book value: evidence from Nigerian economy. Journal of Intellectual Capital, 19(3), 644-668.

xi. Bala, S. A., \& Alhassan, A. (2018). Structural effect of oil price shocks and food importation on economic growth in Nigeria using SVAR model. International Business and Accounting Research Journal, 2(1), 34-46.

xii. Boehm, M., Burdick, D., Reinwald, B., Sen, P., Tatikonda, S., Tian, Y., \& Vaithyanathan, S. (2019). Hybrid parallelization strategies for machine learning programs on top of mapreduce: Google Patents.8(5),66-97.

xiii. Bita, G., Kubaison, S., \& Muketha, M. (2016). Influence of cost leadership as a generic competitive strategy on Microfinance institutions' customer satisfaction in Meru, Kenya. Int. J. Adv. Multidiscip. Res, 3(11), 1-8.

xiv. Bodhanwala, S., \& Bodhanwala, R. (2018). Does corporate sustainability impact firm profitability? Evidence from India. Management Decision, 56(8), 1734-1747.

xv. Bui, B., \& De Villiers, C. (2017). Business strategies and management accounting in response to climate change risk exposure and regulatory uncertainty. The British Accounting Review, 49(1), 4-24.

xvi. Cassia, F., \& Magno, F. (2019). A framework to manage business-to-business branding strategies. EuroMed Journal of Business. 8(6),45-92.

xvii. Cowling, M., Mroczkowski, N., \& Tanewski, G. (2017). Job Creation and Innovation among SMEs in Australia. Paper presented at the ICSB World Conference Proceedings.65-86.

xviii. Clemons, E. K. (2019). Resources, Platforms, and Sustainable Competitive Advantage: How to Win and Keep on Winning New Patterns of Power and Profit (pp. 93-104): Springer.

xix. Dang, C., Li, Z. F., \& Yang, C. (2018). Measuring firm size in empirical corporate finance. Journal of Banking \& Finance, 86, 159-176.

xx. Dobni, C. B., \& Sand, C. (2018). Strategy shift: Integrating strategy and the firm's capability to innovate. Business Horizons, 61(5), 797-808.

xxi. Estrada, I., \& Dong, J. Q. (2019). Learning from experience? Technological investments and the impact of coopetition experience on firm profitability. Long range planning.

xxii. Endrejat, P. C., \& Kauffeld, S. (2018). Can't get no satisfaction? Motivating organisational energy efficiency efforts in Germany. Energy research \& social science, 44, 146-151.

xxiii. Edmondson, V. C., \& Edmondson, V. C. (2018). What Does a Company's Internal Environment Reveal About Its Strategy-Structure Relationship?', The Thinking Strategist: Unleashing the Power of Strategic Management to Identify, Explore and Solve Problems: Emerald Publishing Limited.577-998.

xxiv. Eisman, A. B., Kilbourne, A. M., Dopp, A. R., Saldana, L., \& Eisenberg, D. (2019). Economic Evaluation in Implementation Science: Making the Business Case for Implementation Strategies. Psychiatry research.7(3),81-98.

xxv. FMN. (2019). Annaul Report 2019 Feeding the Nation Everyday. Lagos, Nigeria.

xxvi. Flynn, B., Pagell, M., \& Fugate, B. (2018). Survey research design in supply chain management: the need for evolution in our expectations. Journal of Supply Chain Management, 54(1), 1-15.

xxvii. González-Rodríguez, M. R., Jiménez-Caballero, J. L., Martín-Samper, R. C., Köseoglu, M. A., \& Okumus, F. (2018). Revisiting the link between business strategy and performance: Evidence from hotels. International Journal of Hospitality Management, 72, 21-31.

xxviii. Graça, C. T., \& Zylbersztajn, D. (2019). Business strategies in the context of poorly-delineated land property rights. Revista Brasileira de Gestão de Negócios, 21(3), 506-521.

xxix. Gakuya, R. W., \& Mbugua, D. (2018). effects of cost leadership strategy on customer loyalty among pharmaceutical companies in nairobi county, kenya. European Journal of Social Sciences Studies.4(7),56-88.

xxx. Gupta, G., \& Aggarwal, H. (2016). Analysing customer responses to migrate strategies in making retailing and CRM effective. International Journal of Indian Culture and Business Management, 12(1), 92-127.

xxxi. Hussain, N., Rigoni, U., \& Orij, R. P. (2018). Corporate governance and sustainability performance: Analysis of triple bottom line performance. Journal of Business Ethics, 149(2), 411-432.

xxxii. Hui, K. W., Liang, C., \& Yeung, P. E. (2019). The effect of major customer concentration on firm profitability: competitive or collaborative? Review of Accounting Studies, 24(1), 189-229.

xxxiii. Ituarte, I. F., Salmi, M., Ballardini, R. M., Tuomi, J., \& Partanen, J. (2017). Additive manufacturing in Finland: Recommendations for a renewed innovation policy. Physics Procedia, 89, 70-79.

xxxiv. Jensen, J., Rust, E., \& Mackool, S. (2018). Inflation, Interest Rates, and Equipment Finance: Anticipating and Adapting to a Changing Economic Environment. The Journal of Equipment Lease Financing (Online), 36(3), 1-5. 
xxxv. Kim, M., Song, J., \& Triche, J. (2015). Toward an integrated framework for innovation in service: A resource-based view and dynamic capabilities approach. Information Systems Frontiers, 17(3), 533-546.

xxxvi. Kajola, S. O., Olabisi, J., Ajayi, J. A., \& Agbatogun, T. O. (2018). Determinants of Profitability in Nigerian Listed Deposit Money Banks. Journal of Economics \& Business Research, 24(1).

xxxvii. Kara, A. (2019). The Final Countdown: A Design for Helping Students Implement Business Strategies. Journal of Higher Education Theory and Practice, 19(1), 16-32.

xxxviii. Kafouros, M., \& Aliyev, M. (2016). Institutional development and firm profitability in transition economies. Journal of World Business, 51(3), 369-378.

xxxix. Lubner, C. E. (2019). Bacteria "Read" Light To Gain a Competitive Advantage. Journal of bacteriology, 201(10), e00082-00019.

xl. Liu, Y., Xie, F., \& Xu, Z. (2019). Board Business Connections and Firm Profitability: Evidence from China. Emerging Markets Finance and Trade, 55(9), 1954-1968.

xli. Lawrence, J. M., Crecelius, A. T., Scheer, L. K., \& Patil, A. (2019). Multichannel Strategies for Managing the Profitability of Business-to-Business Customers. Journal of Marketing Research, 56(3), 479-497.

xlii. Maury, B. (2018). Sustainable competitive advantage and profitability persistence: Sources versus outcomes for assessing advantage. Journal of Business Research, 84, 100-113.

xliii. MAN. (2019). Manufacturers can revive nigeria daily nigeria news Retrieved from https://www.manufacturersnigeria.org/ManInDailyNigerianNews.aspx.

xliv. Nakatani, R. (2019). Firm performance and corporate finance in New Zealand. Applied Economics Letters, 26(13), 1118-1124.

xlv. Opara, S. (2018). Flour Mills reports $82 \%$ rise in nine-month profit.

xlvi. Odebode, A., \& Aras, O. N. (2019). The Impact of Globalization on Manufacturing Output: The Case of Nigeria. Adedapo Odebode, Osman Nuri Aras,(2019)." The Impact of Globalization on Manufacturing Output: The Case of Nigeria", Journal of Management, Economics, and Industrial Organization, 3(3), 60-77.

xlvii. Platonova, E., Asutay, M., Dixon, R., \& Mohammad, S. (2018). The impact of corporate social responsibility disclosure on financial performance: Evidence from the GCC Islamic banking sector. Journal of Business Ethics, 151(2), 451-471.

xlviii. O'brien, J. (2019). Category management in purchasing: a strategic approach to maximize business profitability: Kogan Page Publishers.

xlix. Örsdemir, A., Deshpande, V., \& Parlaktürk, A. K. (2018). Is servicization a win-win strategy? profitability and environmental implications of servicization. Manufacturing \& Service Operations Management.

l. Papadas, K.-K., Avlonitis, G. J., Carrigan, M., \& Piha, L. (2019). The interplay of strategic and internal green marketing orientation on competitive advantage. Journal of Business Research, 104, 632-643.

li. Prasad, P., Sivasankaran, N., \& Shukla, A. (2019). Impact of deviation from target working capital on firm profitability: evidence from India. International Journal of Productivity and Performance Management.

lii. Pellegrini, C. B., Caruso, R., \& Cifone, R. (2019). The Impact of ESG Scores on both Firm Profitability and Value in the Automotive Sector (2002-2016).

liii. Oyedokun, G. E., Tomomewo, A. O., \& Owolabi, S. A. (2019). Cost Control and Profitability of Selected Manufacturing Companies in Nigeria. Journal of Accounting and Strategic Finance, 2(1), press-press.

liv. Örsdemir, A., Deshpande, V., \& Parlaktürk, A. K. (2018). Is servicization a win-win strategy? profitability and environmental implications of servicization. Manufacturing \& Service Operations Management. 334-667.

lv. Olson, E. M., Slater, S. F., Hult, G. T. M., \& Olson, K. M. (2018). The application of human resource management policies within the marketing organization: The impact on business and marketing strategy implementation. Industrial Marketing Management, 69, 62-73.

lvi. Pervan, M., Curak, M., \& Pavic Kramaric, T. (2018). The Influence of Industry Characteristics and Dynamic Capabilities on Firms' Profitability. International Journal of Financial Studies, 6(1), 4.

lvii. Shuen, A. (2018). Web 2.0: A Strategy Guide: Business thinking and strategies behind successful Web 2.0 implementations: O'Reilly Media.

lviii. Spyropoulou, S., Katsikeas, C. S., Skarmeas, D., \& Morgan, N. A. (2018). Strategic goal accomplishment in export ventures: the role of capabilities, knowledge, and environment. Journal of the Academy of Marketing Science, 46(1), 109-129.

lix. Sanusi, S., Noor, R. M., Omar, N., Sanusi, Z. M., \& Alias, A. (2017). The Readiness of Small and Medium Enterprises (SME) in Malaysia for implementing Goods and Services Tax (GST). Social Sciences \& Humanities, 25, $241-250$.

lx. Viotti, S., Essenmacher, L., Hamblin, L. E., \& Arnetz, J. E. (2018). Testing the reciprocal associations among coworker incivility, organisational inefficiency, and work-related exhaustion: A one-year, cross-lagged study. Work \& Stress, 32(4), 334-356.

lxi. Wheelock, D. C., \& Wilson, P. W. (2018). The evolution of scale economies in US banking. Journal of Applied Econometrics, 33(1), 16-28.

lxii. Wadho, W., \& Chaudhry, A. (2018). Innovation and firm performance in developing countries: The case of Pakistani textile and apparel manufacturers. Research Policy, 47(7), 1283-1294. 